Journal of Primary Education
$9(3)(2020): 248-257$
UNNES
https://journal.unnes.ac.id/sju/index.php/jpe

\title{
Development of Science Module SETS Approach to Strengthen Cognitive Learning Outcomes of Elementary School Students
}

\author{
Rio Chandra ${ }^{1 凶}$, Enni Suwarsi Rahayu ${ }^{2}$, Ngurah Made Darma Putra ${ }^{2}$ \\ DOI: https://doi.org/10.15294/jpe.v9i3.37713 \\ 1. Sekolah Dasar Negeri 1 Kangkung, Demak, Jawa Tengah, Indonesia \\ 2. Pascasarjana, Universitas Negeri Semarang, Indonesia
}

\begin{abstract}
Article Info
History Articles

Received:

10 February 2020

Accepted:

15 March 2020

Published:

31 May 2020

Keywords:

learning outcomes, module, SETS

Abstract

At present, there is still a lack of teaching materials in Elementary Schools, specifically science that is suitable to the needs of students and encourages students to care about their environment. The purpose of this study is to develop a Natural Sciences module with the STSE (Science, Technology, Society, Environment) approach to strengthen cognitive learning outcomes in Elementary Schools. The method used is the research development of the modified Borg and Gall model, namely preliminary studies, development stages, and evaluation stages. The research subjects were grade IV students, Public Elementary School Kangkung 1 Mranggen. Data collection instruments used were observation sheets, tests, questionnaires, and documentation. Analysis of research with t-test and n-gain test to determine the comparison of modules, as well as improvement of learning outcomes. The results of the study that the Natural Sciences module, with the STSE approach, is valid for use. The results of trials with the t-test show the difference between the use of modules and student books, N-gain module usage scores 0.723 with a very high category. The practicality test shows a practical module so that students and teachers can accept it. The Science Module STSE approach can be used as a substitute for teaching material on the theme of the environment around Grade IV Elementary School.
\end{abstract}




\section{INTRODUCTION}

Natural sciences subjects are one of three topics that are tested as national standardized examinations for elementary school level. Natural sciences are expected to be a vehicle for students to learn about themselves, the environment, and prospects for further development, and to apply it in their daily lives. Curriculum 2013 emphasizes of mutual learning. Cain and Evans (1993) science is a study of the natural surroundings, related to discovery, and contains four things, namely content or products, processes or models, attitudes, and technology.

Based on the results of observations, the classical completeness of natural sciences learning was $63 \%$, existing teaching materials that already used, it is not suitable for students to use in a certain area. They have not been integrated with encouragement so that students can behave appropriately concerning the environment. Ruminiati (2017) stated that the fourth-grade students' books have not applied the scientific approach appropriately, and often there are character values that are not appropriate in the learning context. So the development of teaching materials following these conditions is essential to do.

Rahayu (2015) stated that a module can support students for active learning and can help the effectiveness of learning. Modules are designed according to the needs of students based on the environment so that students more easily understand, integrate, and can be used independently. Integrating material with the environment is assisted with the use of the STSE (Science, Technology, Society, Environment) approach. Sugiarto (2015) explained that STSEbased learning is more effective in increasing creativity for solving environmental problems. It has a positive impact on students than problembased learning through the integration of material and the environment. Sarie et al. (2016) argued that the CTL model with STSE vision can optimize learning outcomes in Elementary School students.

Binadja (2005) stated that STSE education is aimed at helping students know the science, development, and how development influences the environment, technology, and society reciprocally. The STSE approach is used so that students can integrate the material received with the surrounding environment, as well as what behaviors must be done. Yager (2009) stated that STS learning begins with the discovery of problems and then uses the environment. The community as a source of learning and students are active in solving problems that result in more prominence of students' knowledge than those using direct learning. The STSE approach is expected to be able to provide an increase in students' cognitive learning outcomes. Hence, the objective of this research is to develop a natural science module with the STSE approach to strengthening cognitive learning outcomes.

\section{METHODS}

This research development of a natural sciences module with the STSE approach using the Borg and Gall Model modified into three stages. The stage of development can be seen in figure 1. 


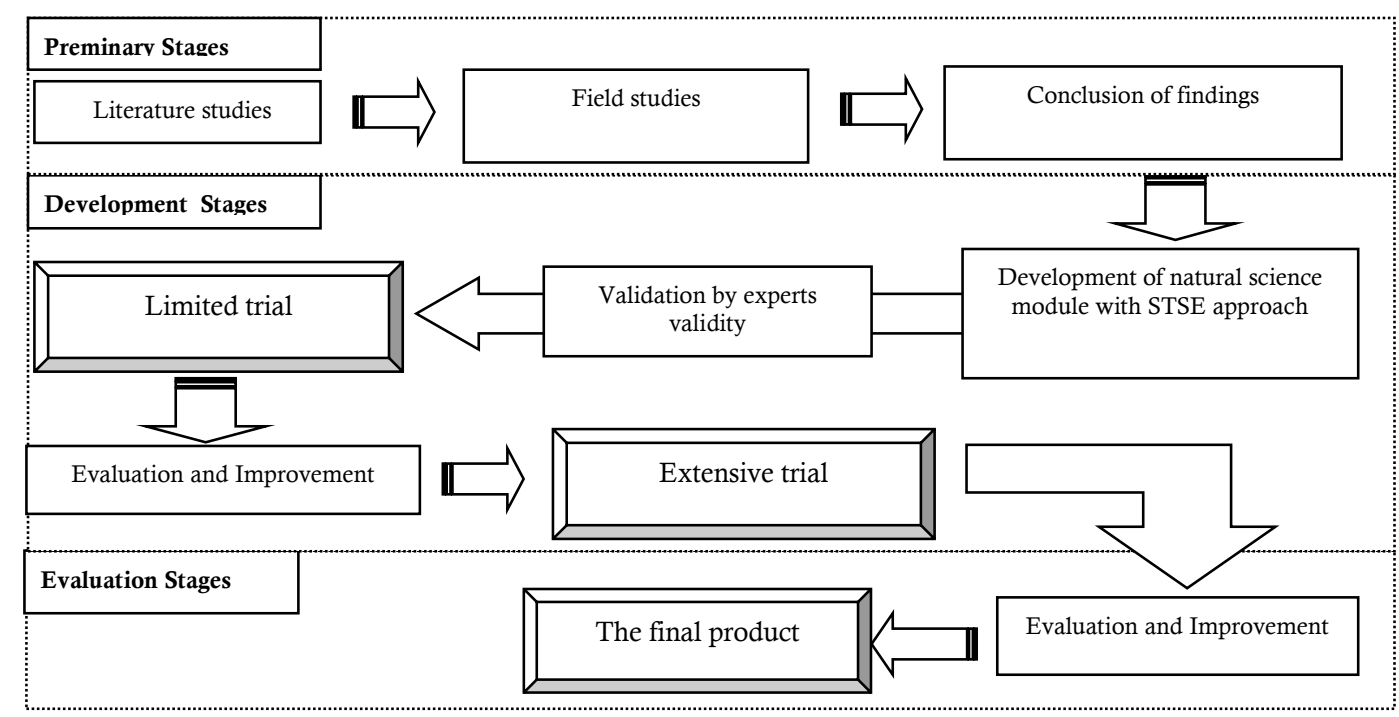

Figure 1. Scheme of Development Module

The research subjects were 60 students in Kangkung 1 Elementary School (30 experiments and 30 controls). Data collection instruments used were observation sheets, tests, questionnaires, and documentation. Module validity is obtained from expert validity. Module effectiveness is obtained from the t-test and $\mathrm{N}$ gain test, and module practicality is obtained from the response questionnaire, both of them accuired from development stage.

\section{RESULTS AND DISCUSSION}

The research conducted produced a product in the form of natural science with module STSE approach with the title Natural Care for the Environment Module. Indriyanti and Susilowati (2010) revealed several advantages of using modules, i.e. (1) increase student motivation, (2) after the evaluation, the teacher, and students can find out which part of the module has been completed or not, (3) students achieve results according to their abilities, (4) learning materials are evenly distributed based on needs, and (5) education is more efficient because learning materials are arranged according to academic levels. So that the STSE approach science module is feasible to be developed based on students' needs, and their relationship with the surrounding environment, before the module can be used for testing, the module must be declared valid by an expert first. Four validators validate the module for validity.

The four validators consisted of two expert validators, Universitas Negeri Semarang (UNNES) lecturers as content validators and media validators, and there are two people as education practitioners in the Elementary Schools concerned. Module validation can be divided into four aspects, namely aspects of eligibility, language, presentation, and graphics, from the four elements being betrayed into 21 assessment indicators. Recapitulation of the results of the four validators' assessments can be seen in Table 1. 
Table 1. Validation Recapitulation Module

\begin{tabular}{llllll}
\hline \multirow{2}{*}{ Code } & \multicolumn{2}{l}{ Module rating scores (Aspect) } & \multicolumn{2}{c}{ Average } \\
\cline { 2 - 5 } & Appropriateness & Language & Presentation & Graphical & \\
\hline V-1 & 5 & 5 & 5 & 4.75 & 4.9 \\
V-2 & 4.38 & 4.50 & 4.60 & 4.50 & 4.3 \\
V-3 & 4.75 & 5 & 4.80 & 4.75 & 4.7 \\
V-4 & 4.75 & 5 & 4.60 & 5 & 4.8 \\
Average & 4.77 & 4.87 & Valid & 4.75 & 4.67 \\
Category & Valid & Valid & & Valid & Valid \\
\hline
\end{tabular}

Based on Table 1, the aspect of language obtains the highest score of 4.87 with the category of valid while the aspect of presentation obtains an average score of 4.60 with the category of valid which is the lowest score of the four elements that are considered valid. In general, the average of each aspect of module validity, if categorized, gets the category valid. While the validity score generally obtained an average of 4.67 with the category of "valid" so the modules developed can be continued for the next stage of testing, namely in limited trials and extensive trials. Valid modules are still being repaired first, based on the validator's advice before being used for further trials. Suggestions and follow-up from the module validity test can be seen in Table 2 of the module improvements.

Table 2. The Module Improvements

\begin{tabular}{|c|c|c|}
\hline $\begin{array}{l}\text { Module } \\
\text { aspects }\end{array}$ & Validator suggestion & Revisions \\
\hline Content & $\begin{array}{l}\text { Please add material to the natural } \\
\text { appearance }\end{array}$ & $\begin{array}{l}\text { Add material to natural features, including } \\
\text { capes, bays, and deltas }\end{array}$ \\
\hline & $\begin{array}{l}\text { The delivery material for bird } \\
\text { watching is adjusted }\end{array}$ & $\begin{array}{l}\text { Adjustment of a delivery material in bird } \\
\text { observation activities }\end{array}$ \\
\hline Language & Improve word writing & Improve word writing \\
\hline Presentation & Improve component layout & Improve component layout \\
\hline Graphical & $\begin{array}{l}\text { Use your documentation first, and } \\
\text { specify the source of the literature that } \\
\text { was taken } \\
\text { The picture or photo is clarified }\end{array}$ & $\begin{array}{l}\text { Use personal documentation, and add } \\
\text { sources to images that are not researchers' } \\
\text { documentation }\end{array}$ \\
\hline
\end{tabular}

Suggestions regarding the improvement of the module are made to improve the words used to be more standardized, as well as simple, so that makes it easier for students to understand the assignments or exercises on the module. Use original photographs or drawings from the design of researchers are preferred to look originality if you take from existing sources. The source of the images or photos is included both from the internet and from printed books. Besides, improvements were also made to the color arrangement, to make it more interesting, and use striking colors, making it attractive for students to read. Improvements can be seen in Figures 2 (a) and (b). 

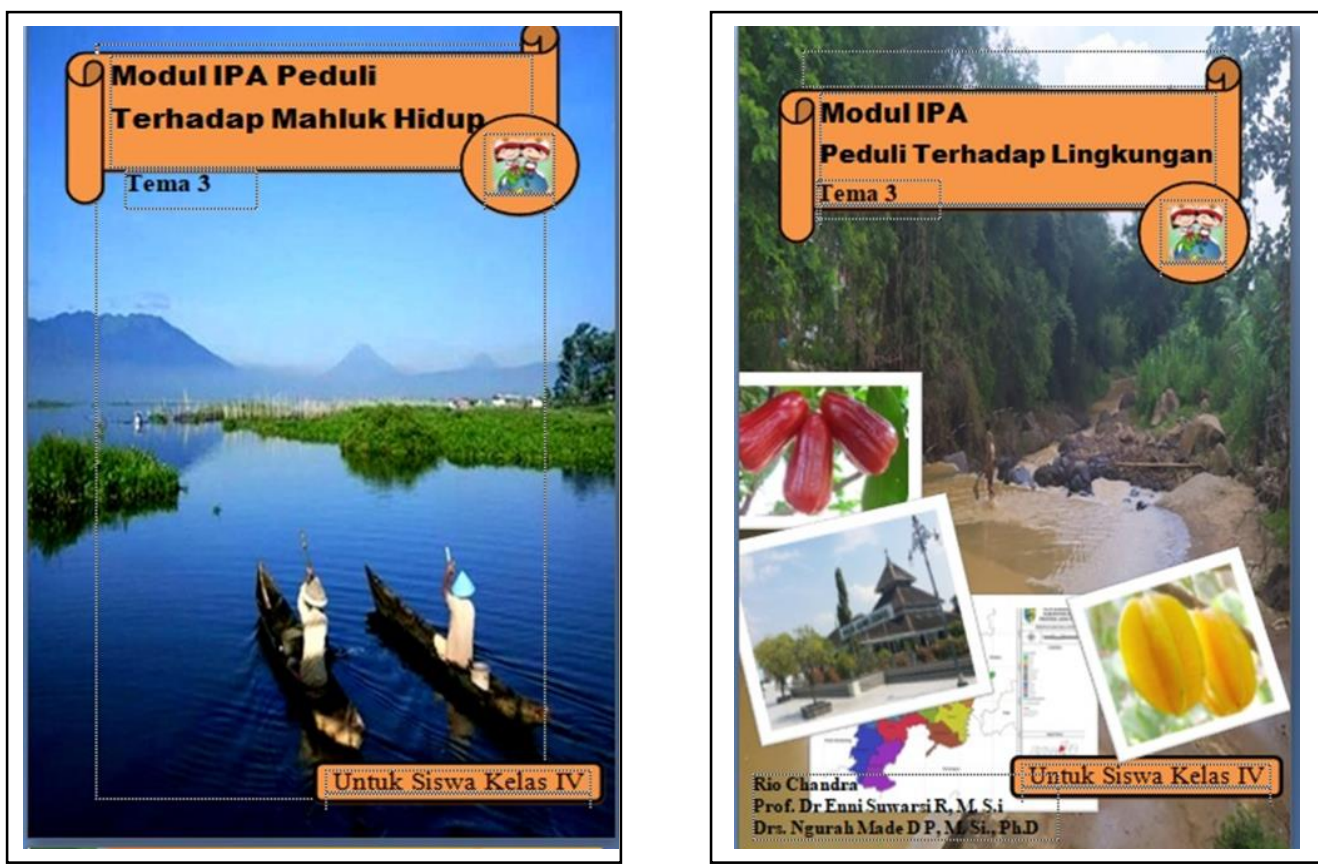

Figure 2a. Cover Before-After Repaired
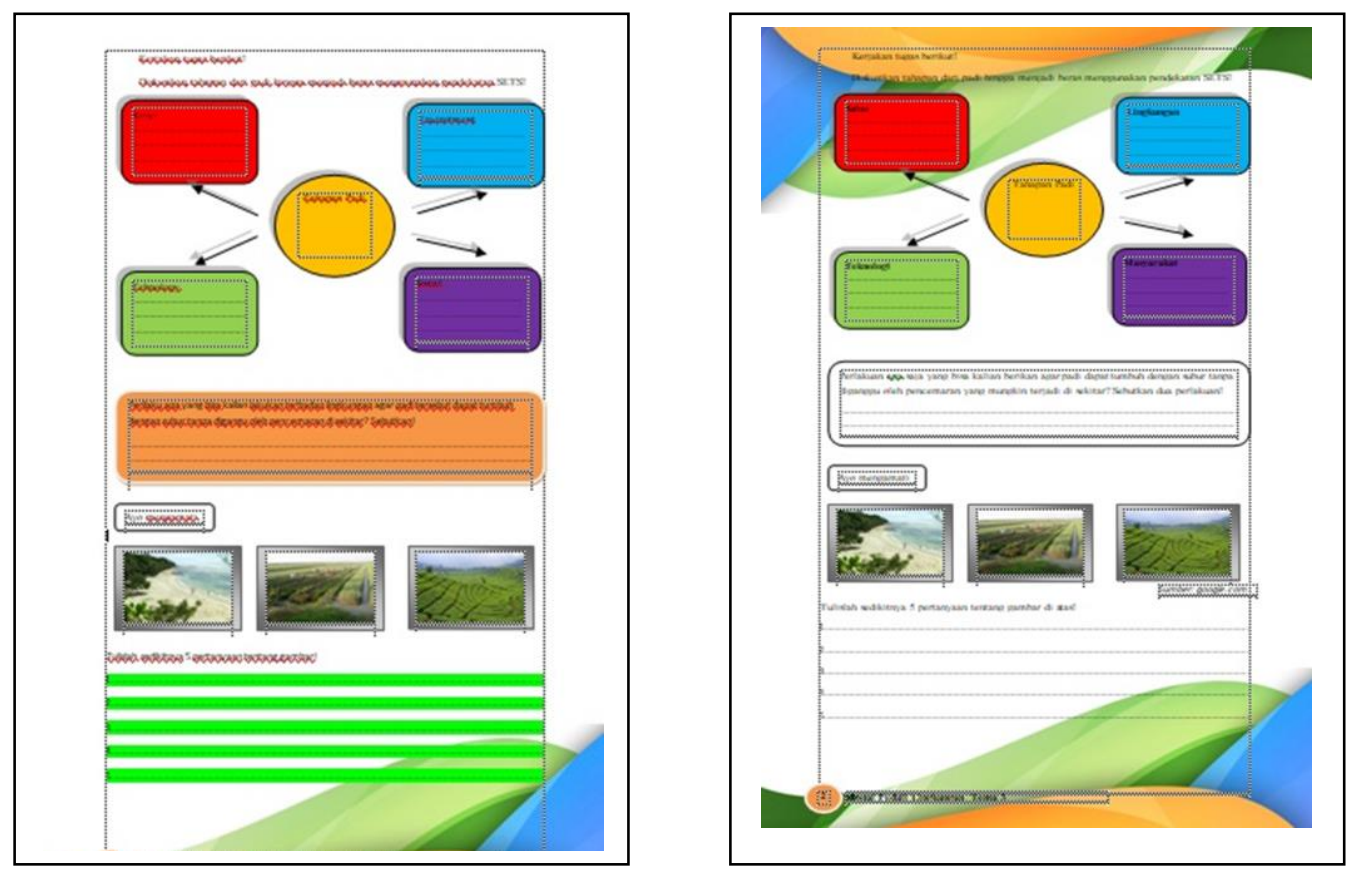

Figure 2b. Color Before-After Repaired

In addition to the module, there is a test observation sheet, and a validator has validated a questionnaire. Each of them gets a valid category, so it can already be used for limited trials. The next step is an instrument that has been validated by an expert validator who conducted a limited trial. The module was limited to 10 elementary school students and got an average score of 4.12 in the very high category, so it can be said that students accept the module. Whereas the 11-item test was conducted for 10 grade IV students who had 
received material about the area where I live and obtained ten questions in the valid and reliable categories.

The extensive trial phase included 60 students in class IV as research subjects with 30 students as the experimental group and 30 students as the control group. The experimental group was treated using the STSE approach module. An extensive trial phase was carried out to determine the effectiveness and practicality of the module further. The effectiveness of the module is demonstrated through student learning outcomes in natural science subjects. Recapitulation of student learning outcomes through pre-test can be seen in Table 3 .

Table 3. Recapitulation of Pre-Test Learning Outcomes

\begin{tabular}{lcc}
\hline Aspect & $\begin{array}{c}\text { Experimental } \\
\text { group }\end{array}$ & $\begin{array}{c}\text { Control } \\
\text { group }\end{array}$ \\
\hline Average & 40.33 & 39.50 \\
Lowest score & 20 & 20 \\
Highest score & 70 & 70 \\
Complete & 1 & 2 \\
Not complete & 29 & 28 \\
Total students & 30 & 30 \\
Completed & & \\
classical (\%) & 3.33 & 6.66 \\
\hline
\end{tabular}

The initial conditions of students in the experimental group and the control group did not experience much difference. The average experimental group was 40.33 , and the control group was 39.50. The completeness obtained for each group can be said to be less than $90 \%$. This proves that almost all students do not know anything about the subject to be studied.

Furthermore, normality tests and homogeneity tests were performed to determine the normality of data for each group, and the similarity between the experimental groups and the control groups. The results of the normality test for each group with 30 students using SPSS 26 , in the experimental group was 0.422 , while in the control group was 0.074 . Both groups get $z>0.05$, which means it can be said that each group is normally distributed.
Whereas to test the similarity of the experimental group, and the control group used a homogeneity test. The homogeneity test used SPSS 26 and obtained the calculated score was 0.696 . The results show that a score $>0.05$, so it can be concluded that the two groups have similar or homogeneous conditions. Next, the pre-test is done after the students are treated. The experimental group did the learning using the science module with the STSE Approach, and the control group using student books. The recapitulation of the post-test results can be seen in Table 4.

Table 4. Recapitulation of Post-Test Learning Outcomes

\begin{tabular}{lcc}
\hline Aspect & $\begin{array}{c}\text { Experimental } \\
\text { group }\end{array}$ & $\begin{array}{c}\text { Control } \\
\text { group }\end{array}$ \\
\hline Average & 83.50 & 74.67 \\
Lowest score & 70 & 70 \\
Highest score & 100 & 90 \\
Complete & 30 & 30 \\
Not complete & 0 & 0 \\
Total students & 30 & 30 \\
Completed & 100 & 100 \\
classical (\%) & & \\
\hline
\end{tabular}

Table 4 reveals the post-test scores between the experimental group and the control group, both of which obtained classical completeness of $100 \%$ with an average of the experimental group of 83.50, and the control group was 74.67. The highest value obtained for the experimental group was 100 , while the control group was 80 . The results of the study are consistent with the opinion of Aditia, et al. (2013) the difference between the control class, and the experimental class shows that modules are more effective in empowering learning outcomes when compared to teaching materials from schools. Rini (2017) stated that STSE approach is more effective in improving elementary school student process skills than conventionally. So it appears that the use of modules is superior to the use of student books from school, as evidenced by the difference in post-test average scores between the two groups 
was 8.83. More clearly, it can be seen in Figure 3.

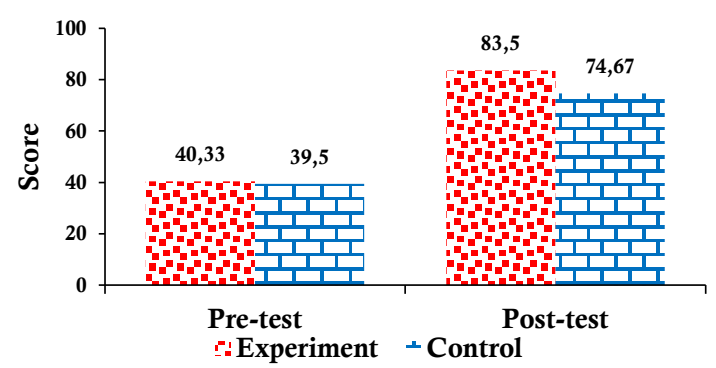

Figure 3. Student Pre-test and Post-test Scores

This is in line with the opinion of Gathong (2019) that STSE approach in addition to increasing understanding of nature, based on knowledge, knowledge can also improve respondents' knowledge of concepts. Atmojo (2018) stated that thematic teaching materials with STSE vision develop students' understanding of energy concepts and get good categories. Esmiyati (2013) has integrated nature science module STSE vision and able to help students to achieve the specified minimum criteria $\geq 75$ so that it is effectively used in grade VII junior high school students. Chowdhury (2017) sated that STSE provided various benefits in learning. From the previous post-test data, it shows that the STSE approach affects the respondents' understanding of concepts, which results in increased learning outcomes or accepted theories regarding the subject, and the respondent's environment.

Also, the t-test was used to measure differences between the two research groups based on scores or post-test scores. From the ttest results obtained a score of $0.1996>0.05$, which means $\mathrm{HO}$ is accepted, so there are differences between the two groups. It is known that the Sig (2-tailed) value of $0.01<0.05$ that $\mathrm{Ha}$ is accepted, so it can be said that the difference is significant. Mahllanurrahman (2017) explains almost the same that the development of learning tools using the STSE approach there is a significant difference in the conceptual understanding of Elementary School students.
The final stage of the module effectiveness test is $\mathrm{N}$-gain and scores 0.723 in the high category. The results of the study are also in line with Lester (2006) an STSE that can improve the understanding of the concepts of fifth-grade Elementary School students on the subject of global warming. Nugraha (2013) stated that STSE visionary teaching materials can improve critical thinking in high school students. Based on the test results, it is known that the use of science modules using the STSE Approach provides a better understanding of concepts and critical thinking levels than student books, which results in a higher average score of the experimental group.

Yoruk (2010) supports this opinion, researched the effects of using STSE on chemistry learning, and concluded that teachers using STSE showed more competence in concepts and new situations. Chowhury (2016) STSE makes a significant contribution to the understanding of student concepts, especially in the natural sciences. Based on this, the students are required to be able to construct thoughts about STSE in learning. This is have agreed with Gil-Pérez and Vilches (2005) that STSE is intended to reconstruct students' thinking, so they can think openly about the state of the surrounding environment, to solve various problems that require several branches of knowledge. The use of science modules with the STSE Approach can significantly reconstruct students' thinking, so that it can help improve student knowledge, especially in the natural sciences subject, and its implementation in the surrounding environment.

While the practicality test module, uses a student response questionnaire and a teacher response questionnaire. The results of the calculation of questionnaire responses of students with a total of 30 children, regarding the Natural Sciences module with the STSE approach, obtained an average score was 4.37 in the very high category. The calculation results show students accept and agree that the module is practically used in learning activities. The responses of the two teachers showed the same thing, namely getting an average score of 3.27 
in the very high category. Teachers can be interpreted to have a very high level of the agreement so that the natural science module with the STSE approach is practical to use.

In general, learning using the natural science module with the STSE approach can improve the cognitive learning outcomes of Elementary School students. This is not separated from the preparation of the module properly. Prastowo (2015) stated that teaching material is a subject that is arranged systematically, to create an atmosphere that allows for learning. Wati (2017) explained that module is a printed teaching subject that is systematically packaged, contains learning objectives, and a means for independent learning. The preparation of material in a systematic module is an essential factor in the development of modules, to increase student understanding in education.

While learning with the STSE approach is learning that integrates subject with its environment from various points of view. Del Rosario (2010) agreed that STSE approach is effective in improving student academic performance as well as students concern for the environment. In line with Binadja (2005), STSE education is aimed at helping students through science, its development, and how scientific development can affect the environment, technology, and society reciprocally. So that the modules in the compilation integrate the STSE approach as a way of thinking of students about learning material, especially in science subjects, modules provide direction regarding activities students must carry out, as well as an evaluation sheet so that the module can also be used independently by students.

Students, through the use of modules, can improve their understanding of the subject, link subject with technology in everyday life, and encourage students to think about the impact on the environment, and how to behave following the environment. Steele (2014) stated the ranked first of the seven components of the excess use of
STSE in learning is that it can explore nature, and can encourage respondents to behave, and interact following nature. In line with this opinion, STSE, which is integrated into the module with the surrounding environment subject, can have a positive impact both for students and for the environment in which they live.

Purwandari et al. (2016) stated that STSE oriented physics modules prove to be feasible because they can improve the learning outcomes of senior high school students. Sadewo et al. (2017) STSE visionary science module can improve junior high school students' understanding of concepts. Winarti et al. (2016) stated that ecological teaching subject with STSE through the PBL Model can improve student learning outcomes. Based on several previous studies have supported the results of research conducted that the development of natural science modules. The STSE approach used valid, effective, and practical, evidenced by the success of the research determined to study, including the validity of module, the effectiveness of the module, and the practicality of the module.

This study found that the use of science modules with a valid STSE approach can be well integrated through various learning activities for students. The results of the integration are found that the STSE approach is very suitable for use in learning, specifically science subjects, to improve student cognitive, which can also be applied to elementary school level learning, not only at secondary and upper education levels. Also, it is known that the use of the STSE approach in general, shows that if students' cognitive about science is good, then the more positive attitude demonstrated by students regarding environmental care behavior. So that this research can further be used as a basis for researchers if you want to connect between cognitive levels and the level of environmental concern they have. 


\section{CONCLUSION}

Based on the results of research conducted on the development of natural science module, is proven to increase students' cognitive learning outcomes. So it can be concluded that the development of the natural sciences module with the STSE approach proved to be valid, effective, and practical use in the learning of grade IV elementary school students.

\section{REFERENCES}

Aditia, M. T., \& Muspiroh, N. (2013). Pengembangan Modul Pembelajaran Berbasis Sains, Lingkungan, Teknologi, Masyarakat Dan Islam (Salingtemasis) Dalam Meningkatkan Hasil Belajar Siswa Pada Konsep Ekosistem Kelas X Di SMA NU (Nadhatul Ulama) Lemahabang Kabupaten Cirebon. Scientiae Educatia: Jurnal Pendidikan Sains, 2(2), 127-148.

Atmojo, S. E., \& Kurniawati, W. (2018). Pengembangan Buku Ajar Tematik Bervisi Sets Untuk Menanamkan Konsep Sustainable And Renewable Energy Siswa Sekolah Dasar. Refleksi Edukatika: Jurnal Ilmiah Kependidikan, 8(2), 156-162.

Binadja, A. (2005). Pedoman Pengembangan Bahan Pembelajaran Bervisi dan Berpendakatan SETS. Semarang: Lab SETS UNNES.

Cain, S E \& Evans, J M. (1993). Sciencing. Second Edition. New York: McGraw-Hill Glencoe.

Chowdhury, M. A. (2017). Towards The Achievement Of A Unified, Uniform And Socially-Just 'Gifted Education'policy Acceptable On A Global Scale. Journal for the Education of Gifted Young Scientists, 5(1), $1-22$.

Del Rosario, B. I. (2010). Pedagogy in Environmental Science for Nonscience Students in Higher Education of Southern Philippines. Liceo Journal of Higher Education Research, 6(2), 60-75.

Esmiyati, E., Haryani, S., \& Purwantoyo, E. (2013). Pengembangan Modul IPA
Terpadu Bervisi SETS (Science, Environment, Technology, and Society) Pada Tema Ekosistem. Unnes Science Education Journal, 2(1), 180-187.

Gathong, S., \& Chamrat, S. (2019, March). PreService Teachers' Teaching Practice Of Science Technology Society Environment (STSE) Learning Approach Integrated Nature Of Science During Internships. AIP Conference Proceedings, 2081(1), 030004-1 - 030004-8

Gil-Pérez, D., \& Vilches, A. (2005). The Contribution Of Science And Technological Education To Citizens' Culture. Canadian Journal of Math, Science \& Technology Education, 5(2), 253-263.

Lester, B. T., Ma, L., Lee, O., \& Lambert, J. (2006). Social Activism In Elementary Science Education: A Science, Technology, And Society Approach To Teach Global Warming. International journal of science education, 28(4), 315-339.

Nugraha, D. A., \& Binadja, A. (2013). Pengembangan Bahan Ajar Reaksi Redoks Bervisi SETS, Berorientasi Konstruktivistik. Journal of Innovative Science Education, 2(1), 28-34.

Purwandari, P., Huriawati, F., Yusro, A. C., \& Wibowo, R. T. (2016). Pengembangan Modul Pembelajaran Fisika Berorientasi SETS pada Materi Listrik Dinamis untuk Meningkatkan Kemampuan Berfikir Kritis Siswa. Jurnal Penelitian LPPM (Lembaga Penelitian dan Pengabdian kepada Masyarakat) IKIP PGRI MADIUN, 2(2), 17.

Prastowo, A. (2015). Panduan Kreatif Membuat Bahan Ajar Inovatif. Yogyakarta: Diva Pres.

Rahayu, W. E., \& Sudarmin, S. (2015). Pengembangan Modul IPA Terpadu Berbasis Etnosains Tema Energi Dalam Kehidupan Untuk Menanamkan Jiwa Konservasi Siswa. Unnes Science Education Journal, 4(2), 920-926.

Rini, C. P. (2017). Pengaruh Pendekatan SETS (Science, Environment, Technology And Society) Terhadap Keterampilan Proses 
Sains Siswa Sekolah Dasar. Pendas: Jurnal Ilmiah Pendidikan Dasar, 2(1), 56-64.

Ruminiati, R., \& Andajani, K. (2017). Analisis Kesesuaian Isi Buku Tematik Kelas IV Sekolah Dasar Dengan Pendidikan Karakter, Dan Pendekatan Scientific. Sekolah Dasar: Kajian Teori Dan Praktik Pendidikan, 25(1), 27-36.

Sadewo, M. A. I., Widowati, A., \& Wibowo, W. S. (2017). Pengembangan Modul IPA Berbasis SETS Untuk Meningkatkan Keterampilan Proses Sains Dan Penguasaan Konsep Peserta Didik . Pend. Ilmu Pengetahuan Alam-S1, 6(7), 370-375.

Sarie, F. N., Rahayu, E. S., \& Isnaeni, W. (2016). Pendekatan Contextual Teaching and Learning Bervisi SETS dalam Mengoptimalkan Multiple Intelligence dan Hasil Belajar. Journal of Primary Education, 5(2), 81-87.

Sugiarto, A., \& Djukri, D. (2015). Pembelajaran Berbasis SETS Sebagai Upaya Meningkatkan Kreativitas Dalam Pemecahan Masalah Pencemaran
Lingkungan. Jurnal Inovasi Pendidikan

IPA, $1(1), \quad 1-11$. https://doi.org/10.21831/jipi.v1i1.4527

Wati, J. M. (2017). Pengembangan Modul Tematik Sumber Energi Bagi Siswa Kelas IV Sekolah Dasar. E-Jurnal Skripsi Program Studi Teknologi Pendidikan, 6(6), 545-557.

Winarti, Y., Indriyanti, D. R., \& Rahayu, E. S. (2015). Pengembangan Bahan Ajar Ekologi Kurikulum 2013 Bermuatan SETS melalui Penerapan Model Problem Based Learning. Lembaran Ilmu Kependidikan, 44(1), 1071-1078.

Yager, R. E. (2009). A Comparation of Students Learning in STS vs Those in Directed Inquary Classes. Journal ofScience Education and Technology, 13(2), 187-208.

Yoruk, Nuray., \& Morgil, I. (2010). The Effects Of Science, Technology, Society, Environment (STSE) Interactions On Teaching Chemistry. Natural science, 2(12), 1417-1424. 